\title{
Morphometric Analysis of Sagittal Otoliths in Coruh Trout (Salmo coruhensis Turan, Kottelat \& Engin, 2010) ${ }^{[*]}$
}

\author{
Recep YILDIZ Savaș YILMAZ* \\ Department of Biology, Faculty of Arts and Sciences, Ondokuz Mayls University, Samsun, Turkey
}

How to cite: Yıldız, R. \& Yılmaz, S. (2021). Morphometric Analysis of Sagittal Otoliths in Coruh Trout (Salmo coruhensis Turan, Kottelat \& Engin, 2010). J. Anatolian Env. and Anim. Sciences, 6(2), 270-277.

Atıf yapmak için: Yıldız, R. \& Yılmaz, S. (2021). Coruh Alabalı̆̆ı (Salmo coruhensis Turan, Kottelat \& Engin, 2010)'nda Sagittal Otolitlerin Morfometrik Analizi. Anadolu Çev. ve Hay. Dergisi, 6(2), 270-277.

D: https://orcid.org/0000-0001-6211-831X *(iD): https://orcid.org/0000-0002-6979-6495

\begin{abstract}
The Coruh trout (Salmo coruhensis Turan, Kottelat \& Engin, 2010) is an anadromous species inhabit south and southeastern Black Sea basin. This study describes the allometric relationships between sagittal otolith (sagitta) measurements and total length (TL) of the Coruh trout collected from the Çam stream (Artvin, Turkey), and the length-weight relationship. A total of 82 individuals were caught with an electroshock device between May 2017 and April 2018. The length $\left(\mathrm{L}_{\mathrm{O}}\right)$, height $\left(\mathrm{H}_{\mathrm{O}}\right)$, weight $\left(\mathrm{W}_{\mathrm{O}}\right)$, perimeter $\left(\mathrm{P}_{0}\right)$, and area $\left(\mathrm{A}_{0}\right)$ of the otolith were recorded for each specimen. Shape indices such as form factor, aspect ratio, circularity, roundness, rectangularity, ellipticity, surface density were calculated using these otolith measurements. Relationships between otolith variables and the somatic growth of fish were defined by the curvilinear function (power model). An analysis of covariance revealed that these relationships did not differ between the left and right sides, and between females and males. All regressions were highly significant $(P<$ 0.001 ) and mean percent prediction error values were less than $7 \%$. The relationships of $\mathrm{L}_{\mathrm{O}}, \mathrm{H}_{\mathrm{O}}, \mathrm{W}_{\mathrm{O}}$, and $\mathrm{P}_{\mathrm{O}}$ against TL were negative allometric, while the TL- $\mathrm{A}_{O}$ relationship was positive allometric. In the analysis of relationships between the otolith shape indices and TL, the values of form factor, roundness, and rectangularity indices decreased with fish somatic growth. In contrast, the circularity and surface density indices increased with fish body length. The length-weight relationship was obtained as $\mathrm{W}=0.0155^{*} \mathrm{TL}^{2.87}$ for overall samples. The difference between the slopes of LWRs of females and males was found insignificant. This study provides the first comprehensive data on the sagittal otolith morphometry of $S$. coruhensis.
\end{abstract}

Keywords: Length-weight relationship, otolith morphometry, Salmo coruhensis, shape index.

\section{Çoruh Alabalığı (Salmo coruhensis Turan, Kottelat \& Engin, 2010)'nda Sagittal Otolitlerin Morfometrik Analizi}

\section{*Sorumlu yazar:}

Savaş YILMAZ

Ondokuz Mayıs Üniversitesi, Fen-Edebiyat

Fakültesi, Biyoloji Bölümü, Samsun, Turkiye

凶: savas.yilmaz@omu.edu.tr
Öz: Çoruh Alabalığı (Salmo coruhensis Turan, Kottelat \& Engin, 2010), Güney ve Güneydoğu Karadeniz havzasında yayılış gösteren anadrom bir türdür. Bu çalışma, Çam Deresi (Artvin, Türkiye)'nden toplanan $S$. coruhensis'in total boyu ile sagittal otolit (sagitta) ölçümleri arasındaki allometrik ilişkileri ve boy-ağırlık ilişkisini tanımlar. Mayıs 2017 ve Nisan 2018 tarihleri arasında elektrossok cihazı ile toplam 82 birey yakalandı. Her bir örnek için otolitin boyu $\left(\mathrm{L}_{\mathrm{O}}\right)$, yüksekliği $\left(\mathrm{H}_{\mathrm{O}}\right)$, ağırlığı $\left(\mathrm{W}_{\mathrm{O}}\right)$, çevresi $\left(\mathrm{P}_{\mathrm{O}}\right)$ ve alanı $\left(\mathrm{A}_{\mathrm{O}}\right)$ kaydedildi. Otolit ölçümleri kullanılarak şekil faktörü, boy-yükseklik oranı, dairesellik, yuvarlaklık, dikdörtgensellik, ovallik, yüzey yoğunluğu gibi şekil indeksleri hesaplandı. Otolit değişkenleri ile balık somatik büyümesi arasındaki ilişkiler eğrisel fonksiyonla (power model) tanımlandı. Kovaryans analizi, bu ilișkilerin sol-sağ bölge ve diși-erkek bireyler arasında farklılık göstermediğini ortaya çıkardı. Tüm ilișkiler oldukça önemliydi $(P<0,001)$ ve ortalama yüzde tahmin hatası değerleri $\% 7$ 'den azdı. TL- $\mathrm{L}_{\mathrm{O}}$, TL- $\mathrm{H}_{\mathrm{O}}$, TL-

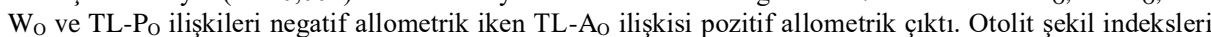
ile balık boyu arasındaki ilişkiler analiz edildiğinde; şekil faktörü, yuvarlaklık ve dikdörtgensellik indeksi değerleri balık somatik büyümesi ile azaldı. Buna karşlık dairesellik ve yüzey yoğunluğu indeksi değerleri balık vücut uzunluğu ile arttı. Tüm bireyler için boy-ağırlık iliskisi $\mathrm{W}=0,0155^{*} \mathrm{TL}^{2,87}$ olarak elde edildi. Diși ve erkeklerin boy-ağırlık ilişkilerinin $b$ parametresi arasındaki fark önemsiz bulundu. Bu çalışma, $S$. coruhensis' in sagittal otolit morfometrisi hakkında ilk kapsamlı verileri sağlar.

Anahtar kelimeler: Boy-ağırlık ilișkisi, otolit morfometrisi, Salmo coruhensis, șekil indeksi. 


\section{INTRODUCTION}

The family Salmonidae, known as salmonids, is native to the Northern Hemisphere (Nelson, 2006). Most of the species belonging to the family have high economic value and are very important for the aquaculture sector (Geldiay \& Balık, 2007). In worldwide, there is 12 valid genus of this family. Among these genera, Salmo is represented by 55 species (Fricke et al., 2021). The genus Salmo contains 16 species in Turkey, 12 of which are endemic to the country (Çiçek et al., 2020; Turan et al., 2020). S. caspius, S. coruhensis and S. pelagonicus are native but not endemic to Turkey (Kaya et al., 2020; Kuljanishvili et al., 2020; Turan \& Bayçelebi, 2020), and S. trutta is an established non-native species occurs only Lake Van and upper Tigris drainages in eastern Anatolia (Kaya, 2020).

The Coruh trout Salmo coruhensis, Turan, Kottelat \& Engin, 2010 is a native freshwater salmonid fish of Turkey. It is known from the area between the Yesilirmak drainage in the west and the Coruh drainage in the east. It is also recorded in Georgia, however, the locality did not specified (Kuljanishvili et al., 2020). This species lives in the lower and middle part of streams and rivers flowing to the south and southeastern Black Sea coasts in Turkey (Turan et al., 2010). S. coruhensis is under threat due to reasons such as habitat degradation and illegal fishing (Okumuş et al., 2006; Verep et al., 2016). It is classified in the "near threatened" category in the Red List of Endangered Species published by the International Union for Conservation of Nature (IUCN) (Freyhof, 2019). Protecting a native species like the Coruh trout necessitates an understanding of its biological and ecological characteristics (Verep et al., 2016). Studies on the biology and ecology of this new species are scarce, and only one paper about its length-weight relationship has been published (Mazlum \& Turan, 2018).

The determination of identity, size, and mass of fish prey from the otoliths found in stomach contents or feces of piscivorous animals may provide significant contributions to available information about foods and feeding habits of these predators (Morley \& Belchier, 2002; Pierce \& Boyle, 1991). Many studies have documented the relationships between otolith morphometry and fish size (e.g. Altin \& Ayyildiz, 2018; Battaglia et al., 2015; Harvey et al., 2000; Iranmanesh et al., 2020; Oliveira et al., 2019). However, a study on the relationships of otolith morphometric parameters with body size is unavailable for the Coruh trout. This study aims to obtain information on the relationships between the sagittal otolith measurements and somatic growth of the
Coruh trout, and the length-weight relationship, testing the hypothesis that such relationships may give useful predictive equations for estimating fish length and weight.

\section{MATERIAL AND METHOD}

Coruh trouts were collected from the Çam stream between May 2017 and April 2018. The Çam stream is located in the borders of the Kemalpaşa district of Artvin Province in the eastern Black Sea region of Turkey. It is formed by the confluence of streams coming from the slopes of İsirli and İncinar hills, situated on the Marnin area of Çamurlu village. In the lower parts, the Çam stream combines with the streams flowing from Kaya and Köprüce villages. It is poured into the Black Sea from the center of the Kemalpaşa district. Its total length from upstream to downstream is approximately $10.3 \mathrm{~km}$ (Anonymous, 2017). The specimens were caught by electrofishing (SAMUS 725MP electro-shocker). A total of 82 individuals (50 females and 32 males) were captured during the sampling period. All samples were kept in a freezer at $-18{ }^{\circ} \mathrm{C}$ for further analysis. All frozen fish were thawed at room temperature, washed in tap water, and dried with a towel paper. Total length $(\mathrm{TL} \pm 0.1 \mathrm{~cm})$, weight $(\mathrm{W} \pm 0.01 \mathrm{~g})$, and sex of each specimen were recorded. The sagittal otoliths (sagittae) were removed, cleaned with distilled water, and stored dry in Eppendorf tubes. Otolith weight $\left(\mathrm{W}_{\mathrm{O}}\right)$ was weighed to the nearest 0.01 $\mathrm{mg}$. The left and right otoliths were photographed on the distal surface under a Leica S8APO binocular microscope connected with a Leica DFC295 digital camera and computer. The following otolith variables were measured using Leica Application Suit ver. 3.8 Image Analysis software: otolith length $\left(\mathrm{L}_{\mathrm{O}}, \mathrm{mm}\right)$, otolith height $\left(\mathrm{H}_{\mathrm{O}}, \mathrm{mm}\right)$, otolith perimeter $\left(\mathrm{P}_{\mathrm{O}}, \mathrm{mm}\right)$, and otolith area $\left(\mathrm{A}_{\mathrm{O}}, \mathrm{mm}^{2}\right)$ (Figure 1). No measurements were taken from otoliths with broken or structural defects.

The relationships of otolith variables with a body length of the Coruh trout were determined by fitting a power equation $\mathrm{Y}=\mathrm{aX}{ }^{\mathrm{b}}$, where $\mathrm{Y}$ is otolith measurement, $\mathrm{X}$ is fish total length, $a$ is the constant and $b$ is the slope (Lleonart et al., 2000). The parameters $a$ and $b$ were estimated by linear regression of the logarithmic transformation of the equation in question. These relationships were generated separately for both left and right otoliths of each sex, and the slopes of regressions were compared with the analysis of covariance (ANCOVA), otolith direction as the main factor, and TL as the covariate (Zar, 1999). When equation slopes did not differ statistically, a single regression was reported for each variable by choosing the left otolith measurements. 


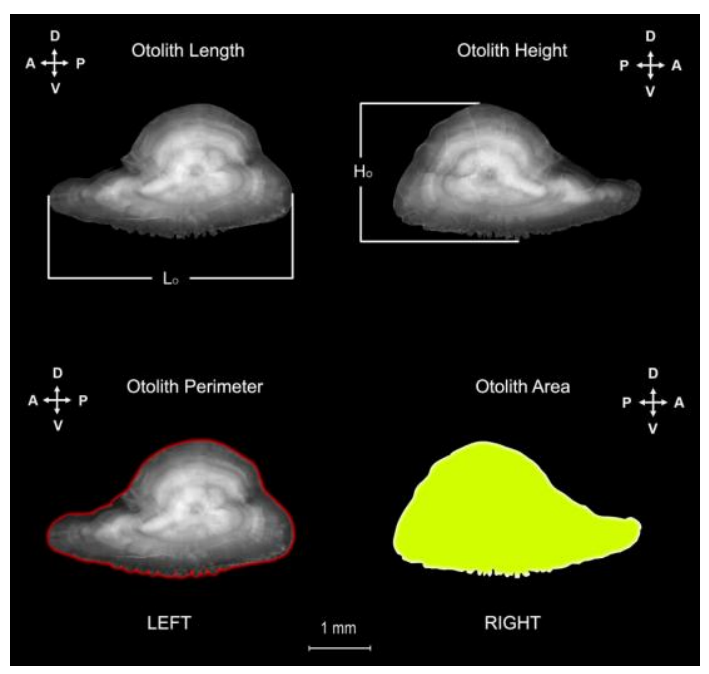

Figure 1. Distal view and morphometric measurements of the left and right otolith of the Coruh trout from the Çam stream, Artvin, Turkey (D, dorsal; V, ventral; A, anterior; $\mathrm{P}$, posterior).

Similarly, the statistical differences in regression slopes between sexes were tested by the analysis of covariance, sex as the main factor, and TL as the covariate (Zar, 1999). When equation slopes did not differ statistically, a single regression was reported for each measurement by pooling the data of both sexes. The significance of the regressions was verified using $F$-test. The deviation of regression slopes from a value corresponding to isometry was checked by the $t$-test (Zar, 1999). The strength of each morphometric relationship was evaluated from the coefficient of determination $\left(r^{2}\right)$ and the mean percent prediction error. The mean percent prediction error for a relationship is the average of the percent prediction error $(\% \mathrm{PE})$ values calculated for all specimens. The percent prediction error $(\% \mathrm{PE})$ for a specimen is obtained by using the following formula (Smith, 1980):

$$
\% P E=\frac{\left|X_{\text {Observed }}-X_{\text {Predicted }}\right|}{X_{\text {Predicted }}} \times 100
$$

The difference between the observed and predicted fish body length was checked for each otolith variable by using a $t$-test, and the Kruskal-Wallis test was used to compare the differences between \%PE values of five otolith measurements (Zar, 1999).

In order to describe the otolith shape of the Coruh trout, the following shape indices were calculated using the left otolith measurements: form factor $=\left(4 \pi \mathrm{A}_{\mathrm{O}}\right) / \mathrm{Po}^{2}$; aspect ratio $=\mathrm{L}_{\mathrm{O}} / \mathrm{H}_{\mathrm{O}}$; circularity $=\mathrm{P}_{\mathrm{O}}^{2} / \mathrm{A}_{\mathrm{O}}$; roundness $=$ $4 \mathrm{~A}_{\mathrm{O}} /\left(\pi \mathrm{L}_{\mathrm{O}}\right)^{2}$; rectangularity $=\mathrm{A}_{\mathrm{O}} /\left(\mathrm{L}_{\mathrm{O}} \times \mathrm{H}_{\mathrm{O}}\right)$; ellipticity $=$ $\left(\mathrm{L}_{\mathrm{O}}-\mathrm{H}_{\mathrm{O}}\right) /\left(\mathrm{L}_{\mathrm{O}}+\mathrm{H}_{\mathrm{O}}\right)$; surface density $=\mathrm{W}_{\mathrm{O}} / \mathrm{A}_{\mathrm{O}}$. The biological meanings of these indices were explained in previous publications (Bani et al., 2013; He et al., 2020). The average values of shape indices calculated for female and male individuals were compared with the $t$-test or
Mann-Whitney U test (Zar, 1999). The correlations between the shape indices and fish body size were also examined.

The length-weight relationship (LWR) of Coruh trout from Çam stream was computed using the equation $\mathrm{W}=\mathrm{aL}^{\mathrm{b}}$, where $\mathrm{W}$ is the total weight of the fish $(\mathrm{g}), \mathrm{L}$ is the total length of the fish $(\mathrm{cm}), a$ and $b$ are the parameters of the equation (Bagenal \& Tesch, 1978). The parameters $a$ and $b$ were estimated by linear regression of logarithmic transformed length-weight data. The slopes $(b)$ of LWRs of females and males were compared for the significant difference by the analysis of covariance (ANCOVA), sex as the main factor, and fish size as the covariate. The $t$-test was applied to confirm whether the slopes were significantly different from 3 , indicating the growth type: isometric $(b=3)$, negative allometric $(b<3)$, or positive allometric $(b>3)$ (Zar, 1999).

\section{RESULTS}

The ANCOVA test showed no significant differences between the coefficients of the regressions generated for the left and right otoliths in each sex (TL vs $\mathrm{L}_{\mathrm{O}}, F=0.001, P=0.977$; TL vs $\mathrm{H}_{\mathrm{O}}, F=0.210, P=0.648$; TL vs $\mathrm{W}_{\mathrm{O}}, F=0.096, P=0.757$; TL vs $\mathrm{P}_{\mathrm{O}}, F=0.138, P=$ 0.712; TL vs $\mathrm{A}_{\mathrm{O}}, F=0.001, P=0.974$ for females and TL vs $\mathrm{L}_{\mathrm{O}}, F=0.045, P=0.832$; $\mathrm{TL}$ vs $\mathrm{H}_{\mathrm{O}}, F=0.405, P=$ 0.527 ; TL vs $\mathrm{W}_{\mathrm{O}}, F=0.134, P=0.716$; TL vs $\mathrm{P}_{\mathrm{O}}, F=$ $0.382, P=0.539$; TL vs $A_{O}, F=0.481, P=0.491$ for males). Therefore, the left otoliths were chosen for subsequent analysis. No statistical differences were found between slopes of females and males for TL-Lo $(F=2.364, P=$ $0.129), \mathrm{TL}^{-H_{\mathrm{O}}}(F=0.971, P=0.328), \mathrm{TL}^{-W_{\mathrm{O}}}(F=0.294$, $P=0.589), \mathrm{TL}_{\mathrm{O}}(F=1.474, P=0.229)$ and TL-Ao $(F=$ $0.001, P=0.977)$. Thus, data of both sexes were combined. The descriptive statistics of fish and otolith measurements are given in Table 1.

Table 1. Descriptive statistics of the Coruh trouts and their sagittal otolith collected from the Cam stream, Artvin, Turkey.

\begin{tabular}{lccc}
\hline Measurement & $\boldsymbol{n}$ & Mean \pm SD & Min-Max \\
\hline Fish length $(\mathrm{cm})$ & 82 & $15.58 \pm 3.78$ & $8.9-26.2$ \\
Fish weight $(\mathrm{g})$ & 82 & $47.68 \pm 33.51$ & $8.34-173.27$ \\
Otolith length $(\mathrm{mm})$ & 76 & $2.72 \pm 0.51$ & $1.85-3.91$ \\
Otolith height $(\mathrm{mm})$ & 76 & $1.59 \pm 0.27$ & $1.10-2.26$ \\
Otolith weight $(\mathrm{mg})$ & 76 & $2.19 \pm 1.03$ & $0.81-4.97$ \\
Otolith perimeter $(\mathrm{mm})$ & 76 & $7.19 \pm 1.46$ & $4.82-11.03$ \\
Otolith area $\left(\mathrm{mm}^{2}\right)$ & 76 & $2.91 \pm 0.97$ & $1.43-5.31$ \\
\hline$n$, sample size; $\mathrm{SD}$, standard deviation; Min, minimum, Max, maximum
\end{tabular}

All relationships were highly significant $(P<$ $0.001)$. In the analysis of morphometric measurements versus fish body length, the regression models explained more than $92 \%$ of the variance in all cases (Table 2). The variable most strongly related to fish size was the otolith area, with $94 \%$ of the variability. The relationships of $\mathrm{L}_{\mathrm{O}}$, 
$\mathrm{H}_{\mathrm{O}}, \mathrm{W}_{\mathrm{O}}$ and $\mathrm{P}_{\mathrm{O}}$ against TL were negative allometric ( $t$-test, TL-Ao, $t=-11.63, P=0.000$; TL-H $, t=-14.83, P=0.000$; TL-W ${ }_{\mathrm{O}}, t=-2.11, P=0.038$; TL-P $\left., t=-8.92, P=0.000\right)$, indicating that the growth of otolith length, height, weight and perimeter is relatively slower than fish length. In contrast, the TL-Ao relationship was positive allometric ( $t$ test, $t=8.48, P=0.000)$, demonstrating that the growth of otolith area is relatively faster than fish growth.
The mean percent prediction errors ranged from 5.24 to 6.12 (Table 2). For each of five otolith measurements, no considerable difference was found between observed and predicted TL values $\left(t\right.$-test, $\mathrm{L}_{\mathrm{O}}, t=-$ $0.063, P=0.950 ; \mathrm{H}_{\mathrm{O}}, t=-0.094, P=0.925 ; \mathrm{W}_{\mathrm{O}}, t=-0.569$, $P=0.570 ; \mathrm{P}_{\mathrm{O}}, t=-0.040, P=0.968 ; \mathrm{A}_{\mathrm{O}}, t=-0.030, P=$ 0.976; d.f. $=150)$. The Kruskal-Wallis test showed that there was no significant difference between the mean \%PE values of the otolith variables $(H=1.509, P=0.825)$.

Table 2. Regression parameters of the relationships between otolith measurements and fish size, and the mean percent prediction error (\%PE) value computed for each variable of the Coruh trout captured from the Çam stream, Artvin, Turkey.

\begin{tabular}{|c|c|c|c|c|c|c|c|}
\hline \multirow[b]{2}{*}{ Relationship } & \multirow[b]{2}{*}{$n$} & \multicolumn{3}{|c|}{ Regression Parameters } & \multirow{2}{*}{$\begin{array}{c}\text { Observed TL } \\
(\text { Mean } \pm \text { SD) }\end{array}$} & \multirow{2}{*}{$\begin{array}{c}\text { Predicted TL } \\
(\text { Mean } \pm \text { SD) }\end{array}$} & \multirow{2}{*}{$\begin{array}{c}\% \mathrm{PE} \\
(\text { Mean } \pm \text { SD) }\end{array}$} \\
\hline & & $a \pm \mathrm{SE}$ & $b \pm \mathrm{SE}$ & $r^{2}$ & & & \\
\hline TL vs $\mathrm{L}_{\mathrm{O}}$ & 76 & $0.381 \pm 0.025$ & $0.721 \pm 0.024$ & 0.923 & $15.44 \pm 3.88$ & $15.48 \pm 4.02$ & $5.65 \pm 4.89$ \\
\hline TL vs $\mathrm{H}_{\mathrm{O}}$ & 76 & $0.252 \pm 0.015$ & $0.674 \pm 0.022$ & 0.925 & $15.44 \pm 3.88$ & $15.49 \pm 3.96$ & $5.82 \pm 4.29$ \\
\hline TL vs $W_{O}$ & 76 & $0.012 \pm 0.002$ & $1.867 \pm 0.063$ & 0.922 & $15.44 \pm 3.88$ & $15.80 \pm 4.07$ & $6.12 \pm 4.38$ \\
\hline TL vs $\mathrm{P}_{\mathrm{O}}$ & 76 & $0.861 \pm 0.059$ & $0.777 \pm 0.025$ & 0.927 & $15.44 \pm 3.88$ & $15.46 \pm 4.01$ & $5.52 \pm 4.39$ \\
\hline TL vs $A_{O}$ & 76 & $0.077 \pm 0.008$ & $1.322 \pm 0.038$ & 0.943 & $15.44 \pm 3.88$ & $15.46 \pm 3.93$ & $5.24 \pm 3.49$ \\
\hline
\end{tabular}

The mean values of seven shape indices are presented in Table 3. For each shape index, there was no significant difference between the mean values of females and males ( $t$-test, rectangularity, $t=-0.588, P=0.558$; surface density, $t=1.092, P=0.279$; Mann-Whitney U test, form factor, $U=686, Z=-0.043 ; P=0.966$; aspect ratio, $U=562, Z=-1.360 ; P=0.174$; circularity, $U=686$, $Z=-0.043 ; P=0.966$; roundness, $U=653, Z=-0.393 ; P$ $=0.694$; ellipticity, $U=562, Z=-1.360 ; P=0.174)$. In the analysis of relationships between the otolith shape indices and fish TL, no correlation is registered for aspect ratio $(r$ $=0.183, P=0.114)$ and ellipticity $(r=0.183, P=0.114)$ indices (Figure 2). The values of form factor $(r=-0.726, P$ $=0.000)$, roundness $(r=-0.382, P=0.001)$ and rectangularity $(r=-0.478, P=0.000)$ indices decrease with fish somatic growth, indicating the otolith becomes geometrically more irregular and less rounded (Figure 3). In contrast to this, the circularity $(r=0.726, P=0.000)$ and surface density $(r=0.837, P=0.000)$ indices increase with fish body length, demonstrating the otolith becomes more circular and thicker (Figure 4).

Table 3. Mean values of shape indices calculated using the left otolith measurements of the Coruh trout from the Çam stream, Artvin, Turkey.

\begin{tabular}{cccc}
\hline Shape indices & $n$ & Mean \pm SD & Min-Max \\
\hline Form factor & 76 & $0.69 \pm 0.05$ & $0.54-0.78$ \\
Aspect ratio & 76 & $1.71 \pm 0.10$ & $1.47-2.00$ \\
Circularity & 76 & $18.08 \pm 1.58$ & $15.96-22.92$ \\
Roundness & 76 & $0.49 \pm 0.03$ & $0.40-0.61$ \\
Rectangularity & 76 & $0.65 \pm 0.02$ & $0.57-0.71$ \\
Ellipticity & 76 & $0.26 \pm 0.02$ & $0.19-0.33$ \\
Surface density & 76 & $0.71 \pm 0.11$ & $0.53-0.98$ \\
\hline$n$, sample size; SD, standard deviation; Min, minimum, Max, maximum
\end{tabular}

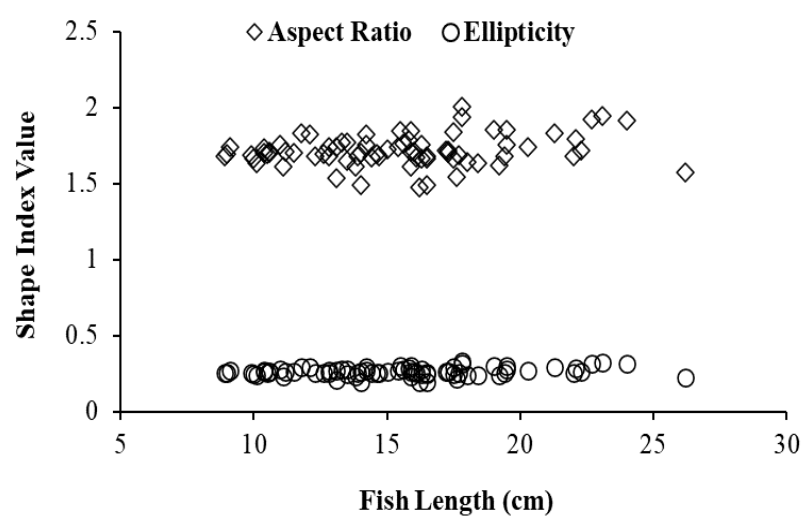

Figure 2. Relationships of aspect ratio and ellipticity indices with fish size in Coruh trout from the Çam stream, Artvin, Turkey.

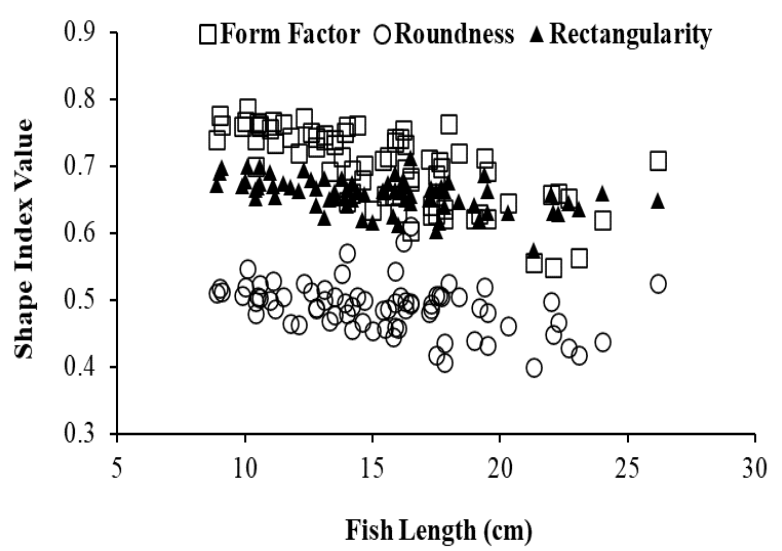

Figure 3. Negative correlations between three shape indices and body length of the Coruh trout from the Çam stream, Artvin, Turkey. 

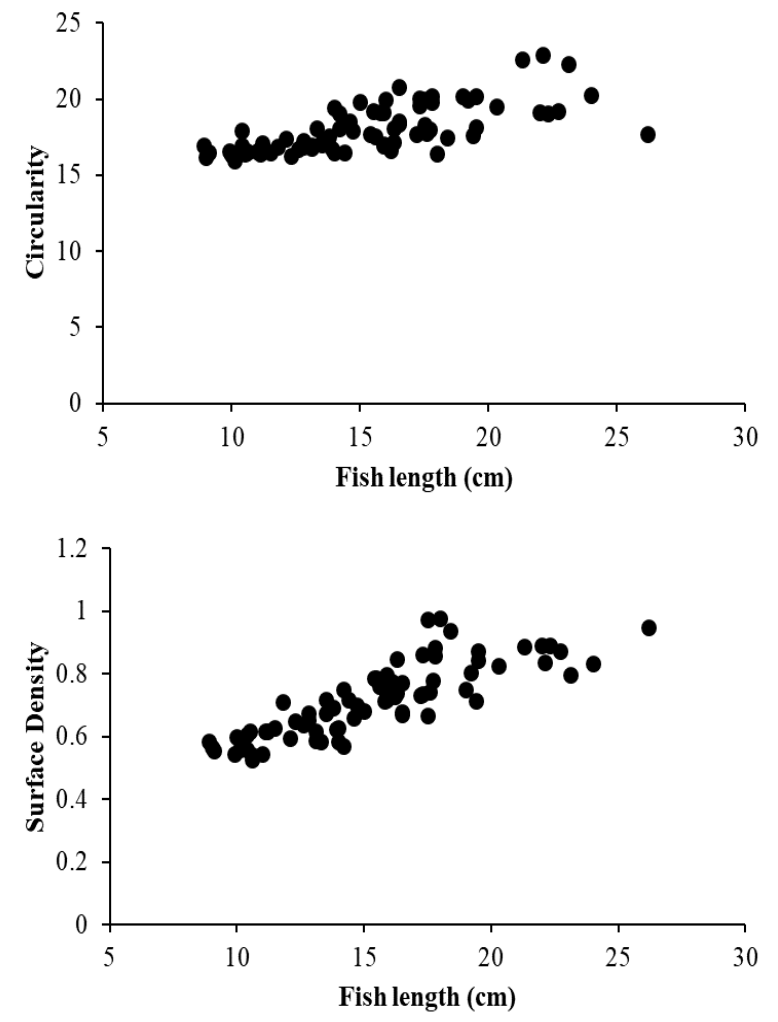

Figure 4. Positive correlations between two shape indices and somatic growth of the Coruh trout from the Çam stream, Artvin, Turkey.

The length-weight relationship of the Coruh trout from the Çam stream was obtained as $\mathrm{W}=0.0155 * \mathrm{TL}^{2.87}$ for overall samples $\left(n=82, \mathrm{SE}(b)=0.032, r^{2}=0.99\right)$. The difference between the slopes of LWRs of females and males was found insignificant (ANCOVA test, $F=0.028, P=0.867$ ). The variation in estimated $b$ value from 3 was statistically significant ( $t$-test, $t=-4.06, P=0.000$ ). This result indicated that the growth of the Coruh trout inhabiting the Çam stream is negative allometric.

\section{DISCUSSION AND CONCLUSION}

As far as we know, this paper represents the first reference on the sagittal otolith morphometry of the Coruh trout. In the analysis of morphometric parameters versus body length of $S$. coruhensis, no significant differences between left and right otoliths and between otoliths of females and males were detected. The same results were also observed for Lutjanus bengalensis (Jawad et al., 2011), Sardinella sindensis (Dehghani et al., 2016), Clarias gariepinus (Y1lmaz et al., 2019), and Silurus glanis (Yazıc1 et al., 2020).

A simple linear model was preferred in many studies that revealed the relationships between otolith variables and fish size (Bal et al., 2018; Daban et al., 2020; Dortbudak \& Ozcan, 2019; Nguyen \& Dinh, 2020). Lleonart et al. (2000) stated that the simple linear function used in the explanation of these relationships is inaccurate for at least two reasons: it cannot distinguish shape heterogeneity and the independent parameter " $a$ " makes no sense in morphometry, where $\mathrm{Y}$ must be 0 when $\mathrm{X}=0$. Moreover, Campana (2004) reported that the abovementioned relationships cannot always be explained by the linear regression model. Therefore, in our study, the allometric power equation was selected to describe the relationships between otolith growth and fish growth. Otolith parameters-body length relationships were previously defined using power models for various fish species (Kanjuh et al., 2018; Kumar et al., 2017; Romero et al., 2020; Saygin et al., 2020; Y1lmaz et al., 2014; Y1lmaz et al., 2015; Y1lmaz et al., 2019).

In this study, the high coefficients of determination and low values of the mean percent prediction error for the relationships between otolith measurements and body length of the Coruh trout showed that fish size can be reliably estimated from otoliths. Similar results were detected in studies of Yilmaz et al. (2014), Y1lmaz et al. (2015) and Yilmaz et al. (2019).

In our study, we found that the otolith length-fish length and otolith height-fish length relationships were negative allometric. The same findings were obtained by Y1lmaz et al. (2014) for Perca fluviatilis from Lake Ladik, Y1lmaz et al. (2019) for Clarias gariepinus from the upper basin of the Sakarya River, and Uyan et al. (2019) for Nemipterus randalli from Gökova Bay. In contrast, these relationships were determined as positive allometric for Anguilla anguilla from Adriatic catchment of Montenegro (Kanjuh et al., 2018) and four demersal species (Genypterus brasiliensis, Acanthistius patachonicus, Pseudopercis semifasciata and Merluccius hubbsi) from the San Matias Gulf, Argentina (Romero et al., 2020). Furthermore, we reported that the relationship between otolith weight and fish length for $S$. coruhensis was negative allometric. This phenomenon was also observed for other fish species such as Acanthopagrus latus, Daysciaena albida, Ellochelon vaigiensis, Mugil cephalus, and Mystus gulio (Qamar et al., 2019). On the other hand, a positive allometric growth pattern was reported by some authors (Kanjuh et al., 2018; Uyan et al., 2019; Y1lmaz et al., 2014). In the current study, the otolith perimeter-fish length relationship was negatively allometric, which agrees with the results of Qamar et al. (2019) for three fish species. But, positive allometric growth was estimated for the relationship between the otolith area and fish length, which in contrast with the findings of Qamar et al. (2019) for five fish species.

In some previous studies (e.g. Bostanc1 et al., 2015; Zischke et al., 2016; Zorica et al., 2010), shape indices were correlated with otolith length. However, Pavlov (2016) stated that the shape indices are 
comparatively independent of otolith length and they should be related to fish size. In our work, a significant correlation between each of the five shape indices and the total length of $S$. coruhensis is registered. These correlations indicate the existence of allometric otolith growth. Similar relationships between the shape indices of the otolith and fish body size are reported in some studies (e.g. Bostancı et al., 2017; Mérigot et al., 2007; Deepa et al., 2019; Pavlov, 2016).

S. coruhensis, which lives in the Çam stream, has shown negative allometric development based on the length-weight relationship. Mazlum \& Turan (2018), on the other hand, found evidence of positive allometric growth $(b=3.084)$. According to Bagenal and Tesch (1978), length-weight relationships in fish change depending on the factors such as food availability, feeding rate, gonad development, and spawning period, all of which were not considered in this study.

In conclusion, it is recommended that the regressions provided in the present study be used within the fish size range limits declared, to prevent errors in the back-calculation of length and weight. Detailed examining the otolith morphology in populations inhabiting different environments of $S$. coruhensis is important for a better understanding of otolith development in this species. It is hoped that the findings of this study would be useful to researchers looking into the feeding habits of possible Coruh trout predators.

\section{ACKNOWLEDGEMENTS}

The authors would like to thank Enes HANÇER and Aykut AYDIN for their assistance in sampling and laboratory processes.

\section{REFERENCES}

Altin, A. \& Ayyildiz, H. (2018). Relationships between total length and otolith measurements for 36 fish species from Gökçeada Island, Turkey. Journal of Applied Ichthyology, 34(1), 136-141. DOI: 10.1111/jai.13509

Anonymous, (2017). Artvin Hopa-Kemalpaşa Çam Deresi Kemer Köprü ve Islahı Raporu. T. C. Orman ve $\mathrm{Su}$ İşleri Bakanlığı Devlet Su İşleri Genel Müdürlüğü 26. Bölge Müdürlüğü, Artvin.

Bagenal, T.B. \& Tesch, F.W. (1978). Age and growth, In: Bagenal, T. (ed.), Methods for assessment of fish production in freshwaters, 101-136p, Blackwell Science Publications, Oxford, UK.

Bal, H., Türker, D. \& Zengin, K. (2018). Morphological characteristics of otolith for four fish species in the Edremit Gulf, Aegean Sea, Turkey. Iranian Journal of Ichthyology, 5(4), 303-311. DOI: 10.22034/iji.v5i4.312
Bani, A., Poursaeid, S. \& Tuset, V.M. (2013). Comparative morphology of the sagittal otolith in three species of South Caspian gobies. Journal of Fish Biology, 82, 1321-1332. DOI: 10.1111/jfb. 12073

Battaglia, P., Malara, D., Ammendolia, G., Romeo, T. \& Andaloro, F. (2015). Relationships between otolith size and fish lenght in some mesopelagic teleosts (Myctophidae, Paralepididae, Phosichthyidae and Stomiidae). Journal of Fish Biology, 87, 774-782. DOI: 10.1111/jfb.12744

Bostancı, D., Polat, N., Kurucu, G., Yedier, S., Kontaș, S. \& Darçin, M. (2015). Using otolith shape and morphometry to identify four Alburnus species (A. chalcoides, A. escherichii, A. mossulensis and A. tarichi) in Turkish inland waters. Journal of Applied Ichthyology, 31(6), 1013-1022. DOI: 10.1111/jai.12860

Bostancı, D., Yedier, S., Kontaş, S., Kurucu, G. \& Polat, N. (2017). Regional variation of relationship between total length and otolith sizes in the three Atherina boyeri Risso, 1810 populations, Turkey. Ege Journal of Fisheries and Aquatic Sciences, 34(1), 11-16. DOI: 10.12714/egejfas.2017.34.1.02

Campana, S.E. (2004). Photographic atlas of fish otoliths of the Nortwest Atlantic Ocean. NRC Research Press, Canada, 284p.

Çiçek, E., Sungur, S. \& Fricke, R. (2020). Freshwater lampreys and fishes of Turkey; a revised and updated annotated checklist. Zootaxa, 4809(2), 241-270.

Daban, İ.B., İhsanoglu, M.A. \& İşmen, A. (2020). Relationships between body size-otolith size for seven demersal fish species from the Marmara Sea, Turkey. Ege Journal of Fisheries and Aquatic Sciences, 37(3), 267-274. DOI: 10.12714./egejfas.37.3.09

Deepa, K.P., Kumar, K.A., Kottnis, O., Nikki, R., Bineesh, K.K., Hashim, M., Saravanane, N. \& Sudhakar, M. (2019). Population variations of Opal fish, Bembrops caudimacula Steindachner, 1876 from Arabian Sea and Andaman Sea: Evidence from otolith morphometry. Regional Studies in Marine Science, 25, 100466. DOI: 10.16/j.rsma.2018.100466

Dehghani, M., Kamrani, E., Salarpouri, A. \& Sharifian, S. (2016). Otolith dimensions (length, width), otolith weight and fish length of Sardinella sindensis (Day, 1878), as index for environmental studies, Persian Gulf, Iran. Marine Biodiversity Records, 9(44), 1-6. DOI: 10.1186/s41200-0160039-0

Dortbudak, M.Y. \& Ozcan, G. (2019). Otolith-body length relationship of Abu Mullet (Planiliza abu (Heckel, 1843)) in Tigris River, Şırnak, Turkey. Fresenius Environmental Bulletin, 28(10), 70887091.

Freyhof, J. (2019). Salmo coruhensis. The IUCN Red List of Threatened Species 2019: e.T19516809A19849589, Accessed:25.03.2021, 
https://dx.doi.org/10.2305/IUCN.UK.2019-

1.RLTS.T19516809A19849589.en.

Fricke, R., Eschmeyer, W.N. \& Van der Laan, R. (2021). Eschmeyer's Catalog of Fishes: Genera, Species, References. Accessed: 15. 03. 2021, http://reseacrharchive.calacademy.org/research/ic hthyology/catalog/fishcatmain.asp.

Geldiay, R. \& Balık, S. (2007). Türkiye tatlısu balıkları, 5. baskl, Ege Üniversitesi Su Ürünleri Fakültesi Yayınları, No:46, Bornova, İzmir, 644p.

Harvey, J.T., Loughlin, T.R., Perez, M.A. \& Oxman, D.S. (2000). Relationship between fish size and otolith length for 63 species of fishes from the Eastern North Pacific Ocean (Report No. 150). NOAA Technical Report NMFS 150, U.S. Department of Commerce Seattle, Washington, $36 \mathrm{p}$.

He, T., Chen, C.J., Qin, J.G., Li, Y., Wu, R.H. \& Gao, T.X. (2020). The use of otolith shape to identify stocks of Redlip Mullet, Liza haematocheilus. Pakistan Journal of Zoology, 52(6), 2265-2273.

Iranmanesh, M., Hesni, M.A. \& Lashkari, M. (2020). Otolith measurements to estimate standard length of gobiid fish (Teleostei: Gobiiformes) from the Persian Gulf and Oman Sea. Indian Journal of Fisheries, 67(4), 138-142. DOI: 10.21077/ijf.2020.67.4.97732-16

Jawad, L., Al-Mamry, J. \& Al-Busaidi, H. (2011). Relationship between fish length and otolith length and width in the lutjanid fish, Lutjanus bengalensis (Lutjanidae) collected from Muscat City coast on the Sea of Oman. Journal of the Black Sea/Mediterranean Environment, 17(2), 116-126.

Kanjuh, T., Mrdak, D., Piria, M., Tomljanovic, T., Joksimovic, A., Talevski, T. \& Milosevic, D. (2018). Relationships of otolith dimension with body length of European eel Anguilla anguilla (Linnaeus, 1758) from Adriatic catchment of Montenegro. Acta Adriatica, 59(1), 91-96. DOI: 10.32582/aa.59.1.74

Kaya, C. (2020). The First Record and Origin of Salmo trutta Populations Established in the Upper Tigris River and Lake Van Basin, Eastern Anatolia (Teleostei: Salmonidae). Journal of Anatolian Environmental and Animal Sciences, 5(3), 366372. DOI: $10.35229 /$ jaes. 777575

Kaya, C., Bayçelebi, E. \& Turan, D. (2020). Taxonomic assessment and distribution of fishes in upper Kura and Aras river drainages. Zoosystematics and Evolution, $\quad \mathbf{9 6}(2)$, 325-344. https://doi.org/10.3897/zse.96.52241

Kuljanishvili, T., Epitashvili, G., Freyhof, J., Japoshvili, J. B., Kalous, L., Levin, B., Mustafayev, N., Ibrahimov, S., Pipoyan, S. \& Mumladze, L. (2020). Checklist of the freshwater fishes of Armenia, Azerbaijan and Georgia. Journal of Applied Ichthyology, 36(4), 501-514. DOI: $10.1111 /$ jai. 14038
Kumar, K. V., Deepa, K. P., Hashis, M., Vasu, C. \& Sudhakar, M. (2017). Relationship between fish size and otolith size of four bathydemersal fish species from the South eastern Arabian Sea, India. Journal of Applied Ichthyology, 33, 102-107. DOI: $10.1111 /$ jai. 13250

Lleonart, J., Salat, J. \& Torres, G.J. (2000). Removing allometric effects of body size in morphological analysis. Journal of Theoretical Biology, 205, 8593.

Mazlum, R. E. \& Turan, D. (2018). Length-weight relationship for twelve species of the genus Salmo L., 1758 (Actinopterygii: Salmonidae) from inland waters of Turkey. Acta Zoologica, 70(3), 407-413.

Mérigot, B., Letourneur, Y. \& Lecomte-Finiger, R. (2007). Characterization of local populations of the common sole Solea solea (Pisces, Solediae) in the NW Metiterranean through otolith morphometrics and shape analysis. Marine Biology, 151, 997-1008. https://doi.org/10.1007/s00227-006-0549-0

Morley, S. \& Belchier, M. (2002). Otolith and body size relationships in bigeye grenadier (Macrourus holotrachys) in Ccamlr Subarea 48.3. Ccamlr Science, 9, 133-143.

Nelson, J. S. (2006). Fishes of the world (Fourth Edition). John Wiley and Sons, Incorporated, 601, Canada.

Nguyen, T.H.D. \& Dinh, Q.M. (2020). Otolith dimensions and their relationship with the size of Glossogobius sparsipapillus fish along the coastline of Mekong Delta, Vietnam. Egyptian Journal of Aquatic Biology and Fisheries, 24(2), 525-533.

Okumuş, I., Kurtoğlu, İ.Z. \& Atasaral, Ş. (2006). General overview of Turkish sea trout (Salmo trutta L.) populations, In: Harris, G. and Milner, N. (eds.), Sea trout: biology, conservation and management, lst ed., 115-127p, Blackwell Publishing, Oxford, UK.

Oliveira, R.R.de S., Andrade, M.C., Machado, F.S., Cunha, É.J.S., Freitas, F.S.de, Klautau, A.G.C. de M., Giarrizzo, T. \& Saint-Paul, U. (2019). Biometric relationships between body size and otolith size in 15 demersal marine fish species from the northern Brazilian coast. Acta Amazonica, 49(4), 299-306.

Pavlov, D. A. (2016). Differentiation of three species of the genus Upeneus (Mullidae) based on otolith shape analysis. Journal of Ichtyology, 56(1), 37-51. DOI: 10.1134/S0032945216010094

Pierce, G. J. \& Boyle, P.R. (1991). A review of methods for diet analysis in piscivorous marine mammals. Oceanography and Marine Biology: An Annual Review, 29, 409-486.

Qamar, N., Panhwar, S.K., Awan, K.P. \& Farooq, N. (2019). Numerical expressions of otolith shape and morphometric relationships for five fish species in tidal-linked lagoons in the northern Arabian Sea. Lakes \& Reservoirs: Research \& Management, 24(4), 354-361. DOI: 10.1111/lre. 12288 
Romero, M.A., Ruiz, N.S., Medina, A.I. \& González, R.A. (2020). Biometric Relationships between Otolith and Fish Size of the Main Demersal Resources of North Patagonia, Argentina. Journal of Ichthyology, $\mathbf{6 0}(3), \quad 411-421 . \quad$ DOI: 10.1134/S0032945220030157

Saygın, S., Özpiçak, M., Yılmaz, S. \& Polat, N. (2020). Otolith shape analysis and the relationships between otolith dimensions-total length of European Bitterling, Rhodeus amarus (Cyprinidae) sampled from Samsun Province, Turkey. Journal of Ichthyology, 60(4), 570-577. DOI: 0.1134/S0032945220040190

Smith, R.J. (1980). Rethinking allometry. Journal of Theoretical Biology, 87, 97-111.

Turan, D. \& Bayçelebi, E. (2020). First record of Salmo pelagonicus Karaman, 1938 (Teleostei: Salmonidae) in the Karamenderes River, Turkey. Journal of Anatolian Environmental and Animal Sciences, 5(4), 551-555. DOI: 0.35229/jaes. 777776

Turan, D., Kalaycı, G., Bektaş, Y., Kaya, C. \& Baycelebi, E. (2020). A new species of trout from the northern drainages of Euphrates River, Turkey (Salmoniformes: Salmonidae). Journal of Fish Biology, 96(6), 1454-1462. DOI: 10.1111/jfb. 14321

Turan, D., Kottelat, M. \& Engin, S. (2009). Two new species of trouts, resident and migratory, sympatric in streams of northern Anatolia (Salmoniformes: Salmonidae). Ichthyological Exploration of Freshwaters, 20(4), 333-364.

Uyan, U., Jawad, L.A., Filiz, H., Tarkan, A.S. \& Çelik, M. (2019). Fish length and otolith size of in Nemipterus randalli Russel, 1986 (Actinopterygii: Perciformes: Nemipteridae) collected from Gökova Bay, Turkey. Thalassia Salentina, 41, 137-146.

Verep, B., Turan, D., Bilgin, S., Terzi, E., Kaya, C. \& Mutlu, T. (2016). Rize akarsu havzalarında doğal alabalık stoklarının bolluğu, antropojenik süreçler ve hidro- elektrik santrallerle etkileşimleri. Anadolu Çevre ve Hayvancılık Bilimleri Dergisi, 1(2), 56-63.

Yazıcı, R., Yazıcıŏglu, O. \& Yılmaz, M. (2020). Otolith morphometry of wels catfish, Silurus glanis L., 1758. Journal of Limnology and Freshwater Fisheries Research, 6(3), 215-222. DOI: 10.17216/limnofish.717925

Yılmaz, S., Emiroğlu, Ö., Aksu, S., Bașkurt, S. \& Polat, N. (2019). Relationships between otolith dimensions and body growth of North African Catfish Clarias gariepinus (Burchell, 1822) from the upper basin of the Sakarya River, Turkey. Croatian Journal of Fisheries, 77(1), 57-62. DOI: 10.2478/cjf-2019-0006
Yılmaz, S., Yazıcıŏ̆lu, O., Saygın (Ayaydın), S. \& Polat, N. (2014). Relationships of the otolith dimensions with body length of European perch, Perca fluviatilis L., 1758 from Lake Ladik, Turkey. Pakistan Journal of Zoology, 46(5), 1231-1238.

Yılmaz, S., Yazıcıoğlu, O., Yazıcı, R. \& Polat, N. (2015). Relationships between fish length and otolith size for five cyprinid species from Lake Ladik, Samsun, Turkey. Turkish Journal of Zoology, 39(3), 438-446. DOI: 10.3906/zoo-1403-58

Zar, J.H. (1999). Biostatiscal analysis (Third Edition), Prentice Hall, New Jersey, USA, 663p.

Zischke, M.T., Litherland, L., Tilyard, B.R., Stratford, N.J., Jones, E.L. \& Wang, Y.G. (2016). Otolith morphology of four mackerel species (Scomberomorus spp.) in Australia: Species differentiation and prediction for fisheries monitoring and assessment. Fisheries Research, 176, 39-47.

Zorica, B., Sinovčič, G. \& Čikeš Keč, V. (2010). Preliminary data on the study of otolith morphology of five pelagic fish species from the Adriatic Sea. Acta Adriatica, 51(1), 89-96. 